\title{
Bimbingan Online Teknik Penulisan Karya Ilmiah Kualitatif dan Kuantitatif
}

\author{
*Masriani ${ }^{1)}$, Muhammad Yusup ${ }^{2)}$, Khairul Anwar ${ }^{3)}$, Syamsiah Nur $^{4)}$, Ferdinan $^{5)}$ \\ 1) Program Studi PGMI STAI Auliaurrasyidin Tembilahan, Indragiri Hilir, Riau, Indonesia \\ 2) Fakultas Syariah Institut Agama Islam Nusantara Batang Hari, Jambi, Indonesia \\ 3) Fakultas Tarbiyah Institut Agama Islam Tebo, Jambi, Indonesia \\ ${ }^{4,5)}$ Program Studi PAI STAI Auliaurrasyidin Tembilahan, Indragiri Hilir, Riau, Indonesia \\ Email: masriani@stai-tbh.ac.id ${ }^{1}$; yusup9253@gmail.com²; alkhair2505@gmail.com³; \\ syamsiah.nur@stai-tbh.ac.id ${ }^{4}$; ferdinan@stai-tbh.ac.id ${ }^{5}$
}

Cara Mensitasi Artikel ini:

Masriani, M., Yusup, M., Anwar, K., Nur, S., \& Ferdinan, F. (2021). Bimbingan online teknik penulisan karya ilmiah kualitatif dan kuantitatif. ABDIMASY: Jurnal Pengabdian dan Pemberdayaan Masyarakat, 2(1), 36-45. $\underline{\text { https://doi.org/10.46963/ams.v2i1.330 }}$

\section{Sejarah Artikel}

Diterima : 27/05/2021

Direvisi : :21/06/2021

Diterbitkan : 29/06/2021

\section{*) Corresponding Author}

masriani@stai-tbh.ac.id

\section{DOI}

https://doi.org/10.46963/ams.v2i1.330

\section{Kata Kunci:}

Penulisan; karya ilmiah;

kualitatif; kuantitatif

Keywords:

Writing; Scientific papers;

Qualitative, Quantitative

\section{Editorial Address}

Kampus Panam (Parit Enam)

STAI Auliaurrasyidin, Jl. Gerilya

No. 12 Tembilahan Barat, Riau,

Indonesia, 29213

abdimasy@stai-tbh.ac.id
Abstract: This paper described the lecturers' community services in providing an online guidance of qualitative and quantitative research methods at STAI Auliaurrasyidin Tembilahan. This guidance was essential to add insight into scientific writing techniques, especially qualitative and quantitative research. The purpose of this guidance was to make both quantitative and qualitative easier to understand because students will not be away from using these methods. This training was accessible online. This guidance was enthusiastically welcomed by students, both from STAI Auliaurrasyidin Tembilahan and others.

Abstrak: Tulisan ini menjelaskan tentang pelaksanaan pengabdian dosen dalam memberikan materi penelitian kualitatif dan kuantitatif di Sekolah Tinggi Agama Islam Auliaurrasyidin Tembilahan, bimbingan ini penting dilakukan untuk menambah wawasan tentang teknik penulisan karya ilmiah khususnya penelitian kualitatif dan kuantitatif. Tujuan dari bimbingan ini untuk memberi kemudahan kepada mahasiswa karena mereka tidak akan terlepas dari penulisan karya ilmiah, contohnya Skripsi(S1), Tesis (S2), Disertasi (S3). Pelatihan ini cukup mudah di akses karena diadakan secara Online. Bimbingan ini disambut antusias oleh mahasiswa baik mahasiswa yang berasal dari Sekolah Tinggi Agama Islam Auliaurrasyidin Tembilahan maupun mahasiswa dari lembaga lain.

cc) (1) This work is licensed under a Creative Commons Attribution-ShareAlike 4.0 International License (CC-BY-SA)

\section{PENDAHULUAN}

Dalam kehidupan sehari-hari kita selalu berhadapan dengan berbagai persoalan atau permasalahan, baik yang bersifat awam maupun masalah yang menuntut pemecahan secara sistematik. Masalah-masalah tersebut pemecahannya sering dengan cara sederhana saja dan bersifat segera dan tidak membutuhkan data-data pendukung, namun tidak sedikit 
permasalahan yang harus disesuaikan dengan dukungan data yang akurat.

Keterampilan menulis karya ilmiah sangat penting artinya bagi mahasiswa dalam rangka mengerjakan tugas-tugas perkuliahannya di perguruan tinggi maupun dalam rangka persiapannya memasuki dunia kerja. Selama mengikuti pendidikan di perguruan tinggi, mau tidak mau, mereka sering diberikan tugas menulis karya ilmiah yang berupa makalah atau artikel berkaitan dengan tugas mata kuliah yang diikutinya. Lebih daripada itu, keterampilan menulis karya ilmiah tentu sangat penting artinya bagi mahasiswa dalam rangka memenuhi salah satu persyaratannya untuk menyelesaikan studinya di perguruan tinggi baik pada jenjang pendidikan D3, S1, S2, maupun S3, keterampilan menulis bagi sebagian besar orang, tidak terkecuali mahasiswa, bukanlah pekerjaan mudah. Keterampilan menulis merupakan keterampilan berbahasa yang paling tinggi tingkatannya dibandingkan keterampilan berbicara, keterampilan membaca, dan keterampilan menyimak (mendengarkan). Hal ini mudah dipahami, karena dilihat dari segi tahapan pemerolehan bahasa, keterampilan menulis dilakukan pada tahapan terakhir setelah pemerolehan keterampilan menyimak, berbicara dan membaca.

kemampuan menyimak dan berbicara bisa timbul melalui proses alamiah , kemampuan menulis tidak diperoleh secara alamiah . Dari empat keterampilan berbahasa yang ada, menyimak, berbicara, membaca, dan menulis, keterampilan menulis, lebihlebih menulis karya ilmiah, dianggap paling sulit. Untuk menguasainya, sungguh diperlukan proses yang memerlukan keterampilan berpikir tingkat tinggi. Menulis bukanlah merupakan aktivitas tunggal, melainkan kompleks karena didahului oleh aktivitas-aktivitas berbahasa yang lain, seperti membaca dan menyimak.

Tidak semua karya tulis boleh disebut sebagai karya ilmiah. Sebuah karya tulis baru dapat digolongkan sebagai sebuah karya ilmiah jika telah memenuhi sejumlah persyaratan, baik dari segi isi, pengerjaan, maupun sosoknya. Dari segi isi, karya ilmiah mengandung kebenaran ilmiah, yaitu kebenaran yang tidak hanya berdasarkan pada rasio, tetapi juga dapat dibuktikan secara empiris. Dari segi pengerjaannya, karya ilmiah disusun berdasarkan metode ilmiah. Selanjutnya, jika dilihat dari segi sosoknya, karya ilmiah disusun sesuai dengan sistematika karya ilmiah yang ada. Sebab itulah, dikenal adanya beberapa jenis karya ilmiah seperti laporan hasil penelitian (Tugas Akhir, Skripsi, Tesis, dan Disertasi), artikel (baik artikel kajian pustaka, dan makalah).

Mendapatkan data akurat dalam menjawab dan memecahkan permasalahan dibutuhkan metode yang sistematik, melihat masalah yang terjadi sehingga menemukan jawaban dan memecahkan masalah itu dapat ditempuh dengan penelitian yang didukung metode yang baik, sehingga ada beberapa pendapat ahli yang menyatakan apabila metode penelitian dalam sebuah penelitian tidak sesuai ketentuan maka akan sangat berpengaruh pada data yang didapatkan. 
Penelitian tidak terlepas dari keseluruhan tahapan kegiatan dan unsurunsur penelitian. Sesuatu yang umum diketahui penelitian memiliki objek penelitian yang berbeda, baik yang berkaitan dengan ilmu sosial atau ilmu pasti. Maka harus ada pemikiran dasar yang menjadi kerangka penelitian tersebut, tipe penelitian apa yang akan dilakukan, metode penelitian apa yang akan digunakan dan variabel penelitian apa yang akan diteliti. Menemukan jawaban adalah tujuan utama dari sebuah penelitian, penelitian dinyatakan berhasil apabila permasalahan atau pertanyaan dari penelitian tersebut terjawab.

Dosen dan mahasiswa adalah kalangan yang sangat dekat dengan penelitian, bahkan menjadi kewajiban ,Dosen dengan Tri Dharma Perguruan tinggi memiliki kewajiban sebagai peneliti demikian pula dengan mahasiswa yang memiliki kewajiban tugas akhir skripsi (SI), tesis (S2), disertasi (S3), maka suatu keharusan untuk terum menambah pengetahuan tentang teknik penulisan karya ilmiah sebagai salah satu tahapan dalam penelitian

Dengan latar belakang permasalahan di atas maka pelaksana sebagai dosen di lingkungan akademik STAI Auliaurrasyidin Tembilahan berinisiatif melaksanakan bimbingan teknik penulisan karya ilmiah kualitatif dan kuantitatif secara online sebagai bentuk pelaksanaan kewajiban pengabdian masyarakat. Kegiatan ini bertujuan mampu mengatasi kesulitan yang ditemui oleh dosen dan mahasiswa dalam pelaksanaan penelitian.

\section{METODE}

Sebagaimana tujuan utama dari pelaksanaan kegiatan bimbingan teknik penulisan karya ilmiah kuantitatif dan kualitatif ini adalah memberikan bimbingan kepada mahasiswa dan dosen dalam pelaksanaan penelitian maka ini dilakukan dengan audiens utama adalah mahasiswa dan dosen seluruh Indonesia pada umumnya dan khusus untuk lingkungan kabupaten Indragiri Hilir

Dengan kegiatan inti pelaksanaan seminar online dengan memberikan materi tentang teknik penulisan karya ilmiah, dengan sesi tanya jawab yang dapat memberikan penjelasan rinci dari permasalahan-permasalahan pada penulisan karya ilmiah yang muncul dari peserta BIMTEK. Peserta BIMTEK berjumlah 250 Peserta, pada aplikasi Zoom dan selebihnya mengikuti secara online dari Youtube, peserta tidak hanya terdiri dari kalangan mahasiswa dan dosen, karena bimtek ini bersifat umum terbuka untuk semua kalangan.

\section{HASIL DAN PEMBAHASAN}

Metode penelitian merupakan cara ilmiah untuk mendapatkan data dengan tujuan dan kegunaan tertentu. Cara ilmiah dengan ciri-ciri Rasional, Empiris dan sistematis. Penelitian adalah pengumpulan dan penyajian informasi yang sistematis ( $\mathrm{S}$ Metode penelitian meliputi pengumpulan data, analisis, interpretasi yang diajukan penelitian untuk studi (Creswell: 2015).

Metode penelitian merupakan cara ilmiah untuk mendapatkan data dengan tujuan dan kegunaan tertentu. Cara ilmiah berarti kegiatan penelitian itu didasarkan pada ciri-ciri keilmuan, yaitu rasional 
,empiris dan sistematis. Rasional berarti dilakukan dengan cara yang masuk akal, empiris berarti cara-cara yang dilakukan dapat diamati oleh indra manusia (Sugiyono,2014:19).

\section{Metode Penelitian Kualitatif}

Metode penelitian kualitatif adalah metode penelitian yang digunakan untuk meneliti pada kondisi objek yang alamiah, di mana peneliti sebagai instrumen kunci, teknik pengumpulan data dilakukan secara triangulasi (Gabungan, analisis data bersifat induktif dan hasil penelitian kualitatif lebih menekankan makna dari pada generalisasi (Sugiyono, 2015).

Bogdan dan Taylor dalam Lexy J. Moleong mendefinisikan metode penelitian kualitatif sebagai prosedur penelitian yang menghasilkan data deskriptif berupa kata-kata tertulis atau lisan dari orang-orang dan perilaku yang dapat diamati (lexy J. Moleong, 2019).

Ciri khusus penelitian kualitatif yang berbeda di setiap tahap proses penelitian

1. Mengeksplorasi permasalahan dan mengembangkan pemahaman terperinci tentang pemahaman sentral

2. Menjadikan tinjauan kepustakaan memainkan peran kecil tetapi menjustifikasi permasalahannya.

3. Menyebutkan maksud dan pernyataan penelitian dalam bentuk open -ended untuk mengungkap pengalaman partisipan.

4. Mengungkapkan data yang didasarkan pada kata-kata (wawancara), gambar (foto) dari sejumlah kecil individu sedemikian rupa sehingga pandangan pera partisipan bisa didapatkan.
5. Menganalisa data untuk deskripsi dan tema dengan menggunakan analisa teks dan menginterpretasi makna yang lebih besar dari temuannya.

6. Menulis laporan dengan menggunakan struktur yang fleksibel dan kriteria evaluatif serta memasukkan reflektivitas dan bias subjektif peneliti. (Creswell, 2015, hlm. 31).

\section{Proses penelitian kualitatif}

Ada tiga kemungkinan masalah yang ada dalam penelitian pertama masalah yang dibawa oleh peneliti tetap hingga sejak awal sampai akhir penelitian sama dengan demikian judul proposal dan laporan akan sama, kedua masalah berkembang yaitu memperdalam dan memperluas masalah yang telah di siapkan, yang ketiga masalah penelitian berubah total. Data tentang masalah kualitatif bisa berasal dari dokumentasi, hasil penelitian, pengawasan, evaluasi, pengamatan dan pernyataan orang yang patut dipercaya.

Menurut Jhon W, Creswell (2003) menyebutkan bahwa tahapan dan prosedur dalam pendekatan kualitatif meliputi langkah-langkah sebagai berikut;

1. The Assumptions of Qualitative Designs.

2. The Type Of Desingn

3. The Reseacher's Role.

4. The Data Collection Procedures

5. Data Recording Procedures

6. Data Analysis Procedures

7. Verification Stepes

8. The Qualitative Narrative

Pendapat lain dari Endang $\mathrm{S}$ Sendyaningsih Mahamit dalam Asep (2007:5) tahapan penelitian kualitatif meliputi: 
1. Menentukan Permsalahan.

2. Melakukan studi literatur.

3. Penetapan lokasi.

4. Studi pendahuluan.

5. Penetapan metode pengumpulan data, observasi, wawancara, dokumen, diskusi terarah.

6. Analisis data selama penelitian.

7. Analisa data setelah validasi dan reliabilitas.

8. Hasil: cerita, personal, deskripsi tebal, naratif, dapat dibantu table frekuensi.

\section{Latar belakang masalah}

Masalah dalam penelitian baik kualitatif dan kuantitatif Menurut Arikunto (2010) yaitu suatu Pendekatan Praktik, dikatakan bahwa masalah itu mesti merupakan bagian dari "kebutuhan" seseorang untuk dipecahkan. Penyebab orang ingin mengadakan penelitian adalah karena ia ingin mendapatkan jawaban dari masalah yang dihadapi. Sementara itu Sedarmayanti, dkk (2011), dalam bukunya Metodologi Penelitian, mengatakan bahwa masalah adalah peristiwa yang terjadi dalam kehidupan kita sehari-hari. Sedangkan apa yang disebut dengan permasalahan penelitian adalah suatu pembatasan fokus perhatian pada ruang lingkupnya sampai menimbulkan pertanyaan dalam diri orang-orang yang mencari permasalahan. Pendapat lain mengatakan bahwa masalah adalah suatu keadaan yang bersumber dari hubungan antara 2 faktor atau lebih yang menghasilkan situasi yang menimbulkan tanda tanya dan dengan sendirinya memerlukan upaya untuk mencari sesuatu jawaban. (Molleong, 2015: 93).

Dari beberapa teori di atas maka dapat disimpulkan masalah-masalah adalah rangkaian sesuatu yang terjadi dalam kehidupan sehari-hari yang menimbulkan pertanyaan dalam setiap individu manusia, serta secara otomatis membutuhkan upaya untuk mencari suatu jawaban masalah tersebut

\section{Fokus penelitian}

Dalam penelitian kualitatif gejala itu bersifat holistik (menyeluruh tak dapat dipisah-pisahkan, sehingga peneliti kualitatif tidak dapat menetapkan penelitiannya berdasarkan variabel penelitian, tetapi keseluruhan situasi sosial yang diteliti yang meliputi aspek tempat (place), pelaku (actor), aktivitas (activity) yang berinteraksi secara sinergis.

Luasnya masalah dalam penelitian kualitatif, peneliti akan membatasi masalah dalam satu variabel atau lebih, batasan masalah dalam penelitian kualitatif disebut fokus penelitian. Dalam fokus penelitian berisi pokok-pokok masalah yang masih bersifat umum.

\section{Rumusan masalah}

Ada beberapa langkah-langkah dalam perumusan masalah yang mana sebagai berikut: pertama, tentukan fokus penelitian, kedua, cari berbagai kemungkinan faktor yang ada kaitannya dengan fokus tersebut dalam hal ini dinamakan sub fokus, ketiga, diantara faktor-faktor yang terkait adakan pengkajian tentang mana yang sangat menarik untuk ditelaah kemudian tetapkan mana yang mau dipilih, keempat, kaitkan secara logis faktor-faktor sub fokus yang dipilih dengan fokus penelitian.

Dalam penelitian kualitatif pertanyaan penelitian dirumuskan atas 
dasar definisi operasional dari suatu variabel penelitian, pertanyaan penelitian kualitatif dirumuskan dengan maksud untuk memahami gejala yang kompleks, interaksi sosial yang terjadi dan kemungkinan ditentukannya hipotesis atau teori baru.

\section{Judul penelitian kualitatif}

Judul penelitian kualitatif tidak harus mencerminkan permasalahan dan variabel yang diteliti. Dalam hal penulisan atau pun menentukan judul, khususnya pada penelitian kualitatif, maka usahakan judul penelitian tidak diawali dengan kata penelitian, studi, atau pun kajian. Buatlah judul penelitian bersifat umum, belum terfokus, sehingga memberi kemungkinan untuk berkembang sesuai dengan kondisi yang dihadapi di lapangan, dan tidak menggambarkan variabel-variabel. (Efianingrum)

\section{Populasi dan sampel}

Populasi adalah objek atau subyek yang mempunyai karakteristik dan kualitas tertentu yang telah ditentukan oleh peneliti untuk dipelajari dan ditarik kesimpulannya dalam penelitian kualitatif dinamakan sebagai nara sumber, partisipan, informan. Tahnik pengambilan sampel.

\section{Teknik Pengambilan Sampel}

Teknik pengambilan sampel untuk menentukan sampel yang akan digunakan dalam penelitian, terdapat berbagai teknik sampling yang digunakan. teknik pada dasarnya dapat yang dikelompokkan menjadi dua yaitu Probability Sampling dan Non-Probability Sampling.

Probability Sampling meliputi Simple random, proportioned stratified random, disproportionate stratified random, dan area random, Nonprobability Sampling meliputi sampling kuota, sampling aksidental, purposive sampling, sampling jenuh dan snowball sampling,

\section{Teknik pengumpulan data}

Dalam penelitian kualitatif secara umum teknik pengumpulan data terdapat empat macam teknik pengumpulan data yaitu observasi, menurut Nasution dalam Sugiono observasi adalah dasar ilmu pengetahuan para ilmuan dapat bekerja berdasarkan data, yaitu fakta mengenai dunia kenyataan yang diperoleh melalui observasi, wawancara, dokumentasi, triangulasi.

\section{Metode Penelitian Kuantitatif}

Dari segi perspektifnya penelitian kuantitatif lebih menggunakan pendekatan etik, dalam arti bahwa peneliti mengumpulkan data dengan menetapkan terlebih dahulu konsep sebagai variabelvariabel yang berhubungan yang berasal dari teori yang sudah ada yang dipilih oleh peneliti. Kemudian variabel tersebut dicari dan ditetapkan indikatorindikatornya. Hanya dari indikator yang telah ditetapkan tersebut dibuat kuesioner, pilihan jawaban dan skor-skornya. Sebaliknya penelitian kualitatif lebih menggunakan perspektif emik. Peneliti dalam hal ini mengumpulkan data berupa cerita rinci dari para informan dan diungkapkan apa adanya sesuai dengan bahasa dan pandangan informan (Hamidi, 2004).

Dari segi konsep atau teori, penelitian kuantitatif bertolak dari konsep (variabel) yang terdapat dalam teori yang dipilih oleh peneliti kemudian dicari datanya,

\footnotetext{
ABDIMASY: Jurnal Pengabdian dan Pemberdayaan Masyarakat 
melalui kuesioner untuk pengukuran variabel-variabelnya. Di sisi lain penelitian kualitatif berangkat dari penggalian data berupa pandangan responden dalam bentuk cerita rinci atau asli mereka, kemudian para responden bersama peneliti memberi penafsiran sehingga menciptakan konsep sebagai temuan. Secara sederhana penelitian kuantitatif berangkat dari konsep, teori atau menguji (retest) teori, sedangkan kualitatif mengembangkan, menciptakan, menemukan konsep atau teori. Penelitian tidak akan terlepas dari apa yang disebut variabel penelitian, variabel penelitian adalah suatu atribut atau sifat dari orang, obyek atau kegiatan yang mempunyai variasi tertentu yang ditetapkan oleh peneliti untuk di pelajari dan ditarik kesimpulannya, Dalam penelitian kuantitatif ada beberapa macam variabel yaitu:

\section{Variabel Independen}

1. Variabel independen sering disebut variabel bebas adalah yang mempengaruhi atau yang menjadi sebab perubahan atau timbulnya variabel dependen. Variabel independen sering disebut variabel eksogen.

2. Variabel dependen, disebut juga dengan variabel terikat, variabel terikat adalah variabel yang dipengaruhi atau yang menjadi akibat karena adanya variabel bebas, variabel dependen ini sering disebut juga dengan variane indogen.

3. Variabel moderator, adalah variabel yang, bisa memperkuat atau memperlemah hubungan antar variabel. Contoh hubungan pendidikan dan keberhasilan usaha , lingkungan bisa jadi variabel moderator.

4. Variabel intervening, Dari segi hipotesis, penelitian kuantitatif merumuskan hipotesis sejak awal, yang berasal dari teori relevan yang telah dipilih, sedang penelitian kualitatif bisa menggunakan hipotesis dan bisa tanpa hipotesis. Jika ada maka hipotesis bisa ditemukan di tengah penggalian data, kemudian "dibuktikan" melalui pengumpulan data yang lebih mendalam lagi.

\section{Proses penelitian kuantitatif}

Dalam penelitian kuantitatif masalah yang diteliti sudah jelas, setelah masalah diidentifikasi dan dibatasi maka selanjutnya masalah tersebut di dirumuskan. Rumusan masalah pada umumnya dinyatakan dalam kalimat pertanyaan, pertanyaan ini yang akan menjadi panduan kegiatan selanjutnya. Menjawab rumusan masalah dapat digunakan berbagai teori.

Masalah dalam penelitian dapat diartikan penyimpangan antara yang seharusnya dengan apa yang benar-benar terjadi, masalah-masalah dalam penelitian kuantitatif ada beberapa macam diantaranya: terjadi penyimpangan antara pengalaman dengan kenyataan, terdapat penyimpangan antara apa yang telah direncanakan dengan kenyataan, ada pengaduan, ada kompetisi..

\section{Latar belakang masalah}

Masalah yang diteliti tentunya dimunculkan melalui serangkaian proses penalaran tertentu dari sumber-sumber tertentu; jadi ada "konteks" tertentu, yang dari situ (dengan bantuan kemampuan penalaran) kita dapat merumuskan 
"masalah penelitian"; yakni masalah yang kita pilih dan kita usulkan untuk diteliti. Uraian dan penjelasan yang demikian itulah yang mesti dipaparkan dalam "Latar Belakang Masalah". Sesuatu yang belum jelas, sesuatu yang masih tanda Tanya, sesuatu yang belum terketahui secara pasti, dan jawabannya terletak atau bergantung pada kenyataan empiris, itulah yang (dalam penelitian kuantitatif) disebut dan dimunculkan sebagai "masalah penelitian". Namun, yang menjadi pertanyaan adalah: "Mengapa ia dinilai dan dimunculkan sebagai "masalah"? apa yang melatarbelakanginya sehingga ia disebut dan dimunculkan sebagai "masalah"? dalam konteks seperti itulah, "Istilah Latar Belakang Masalah" kita gunakan di dalam menyusun usulan/rancangan penelitian (Faisal, 1999).

\section{Rumusan masalah}

Rumusan masalah merupakan suatu pernyataan yang dicarikan jawabannya melalui pengumpulan data, rumusan masalah dan masalah sangat erat kaitannya karena setiap rumusan masalah penelitian harus berdasarkan masalah. Beberapa bentuk rumusan masalah yaitu rumusan masalah deskriptif, rumusan masalah deskriptif, yang berkenaan dengan variabel mandiri baik hanya satu variabel atau lebih, rumusan masalah komparatif, rumusan masalah komparatif adalah rumusan masalah yang memperbandingkan keberadaan satu variabel atau lebih pada dua atau lebih sampel yang berbeda atau pada waktu yang berbeda.

\section{Landasan teori}

Wiliam wiersma menyatakan dalam Sugiono teori adalah generalisasi atau kumpulan generalisasi yang dapat digunakan untuk menjelaskan berbagai fenomena secara sistematik. Mark dalam Sitirahayu Haditono membedakan ada tiga macam teori yang berhubungan dengan data empiris ,antara lain:

1. Teori yang deduktif, memberi keterangan yang dimulai dari suatu perkiraan atau pikiran spekulatif tertentu ke arah data akan diterangkan

2. Teori yang induktif cara menerangkan dari data ke arah teori dalam bentuk ekstrem titik pandang yang positivistik ini dijumpai pada kaum behaviorist.

3. Teori yang fungsional, di sini tampak suatu interaksi pengaruh antara data dan perkiraan teoritis, yaitu data mempengaruhi pembentukan teori dan pembentukan teori kembali mempengaruhi data

Berdasarkan data dapat ditarik kesimpulan, teori adalah suatu konseptualisasi yang umum dan dapat di uji kebenarannya, apabila tidak maka itu bukan teori. Ada beberapa fungsi teori antara lain untuk memperjelas dan mempertajam ruang lingkup atau konstruk variabel yang akan diteliti, prediksi dan pemandu untuk menentukan fakta dalam merumuskan hipotesis dan menyusun hipotesis, sebagai kontrol dalam membalas hasil penelitian .

\section{Kerangka berpikir}

Kerangka berpikir merupakan model konseptual tentang bagaimana teori berhubungan dengan berbagai faktor yang telah diidentifikasi sebagai masalah yang penting. Teori-teori adalah 
argumentasi dasar dalam penyusunan kerangka berpikir yang membuahkan hipotesis, kerangka berpikir merupakan penjelasan sementara terhadap gejalagejala yang menjadi objek permasalahan (Suriasumantri, 1986 dalam Sugiyono, 2014). Alur -Alur berpikir yang logis dalam membangun kerangka berpikir dapat membuahkan kesimpulan yang berupa hipotesis dan sintesis hubungan antar variabel yang disusun dari berbagai teori yang telah di deskripsikan.

\section{Hipotesis}

Hipotesis merupakan jawaban sementara terhadap rumusan masalah penelitian. Penelitian yang merumuskan hipotesis adalah penelitian yang menggunakan pendekatan kuantitatif selanjutnya hipotesis, selanjutnya hipotesis tersebut akan di uji peneliti dengan menggunakan kuantitatif. Ada perbedaan antara hipotesis penelitian dan hipotesis statistik, hipotesis penelitian seperti yang dijelaskan di atas, hipotesis statistik ada apabila penelitian bekerja dengan sampel.. Ada beberapa macam hipotesis penelitian Yaitu:

1. Hipotesis Deskriptif, merupakan jawaban sementara terhadap masalah deskriptif, yaitu yang berkenaan dengan variabel mandiri.

2. Hipotesis Komparatif, merupakan jawaban sementara terhadap rumusan masalah komparatif, pada rumusannya ini variabelnya sama tetapi populasi atau sampelnya berbeda atau keadaan itu terjadi pada waktu yang berbeda.

3. Hipotesis asosiatif, merupakan jawaban sementara terhadap rumusan masalah asosiatif, yaitu yang menanyakan hubungan antara dua variabel atau lebih.

\section{SIMPULAN}

Bimbingan online teknik penulisan karya ilmiah kualitatif dan kuantitatif yang dilaksanakan di Sekolah Tinggi Agama Islam Auliaurrasyidin Tembilahan sudah berhasil dilaksanakan dan memberikan dampak positif dalam menambah wawasan mengenai teknik penulisan karya ilmiah khususnya penelitian kualitatif dan kuantitatif dan akan membawa kemudahan dalam penyelesaian tugas akhir mahasiswa( Skripsi). Bimbingan ini lakukan secara online, hal ini menjadi suatu kemudahan untuk mengikuti, sehingga bimbingan ini dapat maksimal dilaksanakan

Dengan adanya bimbingan, mahasiswa menjadi lebih mengerti tentang pentingnya kemampuan menulis karya ilmiah sebagai bagian dari sumbangan pemikiran dan gagasan intelektual. Mereka telah memahami definisi karya ilmiah, tujuan-tujuan penulisan karya ilmiah, manfaat menulis karya ilmiah, karakter-karakter tulisan ilmiah, latar belakang masalah, rumusan masalah, landasan teori, kesimpulan, dan memahami secara rinci metodologi dan tahapan tahapannya

\section{DAFTAR PUSTAKA}

Arikunto, S. (2010). Prosedur Penelitian Suatu pendekatan Praktek. Jakarta: Rineka Cipta.

Creswell, J. (2015). Riset Pendidikan Perencanaan, Pelaksanaan, dan Evaluasi Riset Kualitatif \& Kuantitatif. Jakarta. 
Faisal, S. (1999). Format-format Penelitian Sosial. Jakarta: PT Raja Grafindo Persada

Hamidi. (2004). Metode Penelitian Kualitatif: Aplikasi Praktis Pembuatan Proposal dan Laporan Penelitian. Malang: UMM Press.

Lexy J. M. (2019). Metodelogi Penelitian Kualitatif. Bandung: Rosdakarya.

M. Taufiq, A. (2015). Merancang Kuesiner Konsep dan panduan Untuk Penelitian Sikap, Kepribadian \& Prilaku. Jakarta: Prenada Group.

Sedarmayanti., Hidayat., Syarifudin. (2011). Metodologi Penelitian. Bandung: CV Mandar Maju

Sugiyono. (2014). Metode Penelitian Kuantitaf kualitatif dan $R \& D$. Jakarta: Alfabeta. 